\title{
The Impact of Fiscal Policy on Investment in Libya (2000-2015)
}

\author{
Mustafa Khalifa Thawadi El. Hamoudi \\ Social Sciences Institute, Department of Business Administration, Kastamonu University, Kastamonu, Turkey \\ Email: Mustafa6321@yahoo.com
}

How to cite this paper: Hamoudi, M.K.T.E. (2016) The Impact of Fiscal Policy on Investment in Libya (2000-2015). Open Access Library Journal, 3: e3184.

http://dx.doi.org/10.4236/oalib.1103184

Received: November 30, 2016

Accepted: December 27, 2016

Published: December 30, 2016

Copyright $\odot 2016$ by author and Open Access Library Inc.

This work is licensed under the Creative Commons Attribution International License (CC BY 4.0).

http://creativecommons.org/licenses/by/4.0/

\section{(c) (i) Open Access}

\begin{abstract}
The fiscal policy effect on the investment spending in Libya is a study of the simple connection test which is a detailed study because it covers the period 2000-2015 and it selects the multiple regression model in a study to evaluate the effect of the fiscal policy on the investment spending by using the gross domestic product, the government spending. In this study, some of the related literature has been discussed and it has been done under three subtitles: a theoretical, experimental and analytical review and study. The study shows that the gross domestic product has a positive effect on the investment spending in Libya and growth in gross domestic product (GDP) will lead to the expansion of investment spending in Libya during the study period (20002015).
\end{abstract}

\section{Subject Areas}

Business Finance and Investment

\section{Keywords}

Fiscal Policy, Foreign Direct Investments, Dependent Variables, Data Analysis and Relationship

\section{Introduction}

The role of fiscal policy in economic growth has an important place in economic research and economic theory. Traditional role of fiscal policy in the classical economic theory is considered to be in fostering sustainable long-term fiscal policy of the most important economic policy tools to achieve economic development and eliminate the problems that hinder economic stability, as well as its impact on economic development, especially in the growing countries to grow, thanks to this de- 
velopment, it became necessary to state guidance of the national economy in all its aspects, and has become a financial policy that plays a key role in achieving objectives of the national economy. It was the increased attention to foreign direct investment, of its crucial role in economic development, Libya is one of these countries, which focused on improving foreign investment climate, but it was without ambition.

Libya has the chance to let go its past and renew the infrastructure for its economy, but it should also continue the commitment of doing comprehensive repair to make its full potential when the transparency helps to stop the uncertainty or the investor confidence and helping, with attracting skilled immigrant which mostly needed by the country, plus attracting the foreign experiences and foreign investment (as discussed by International Monetary fund report in 2012) [1].

Libya worked to make an arrangement for the repairing and the openness since the punishment of the United state had frozen in 1999, but the progress of the establishment of the market economy was so slow and intermittent when Libya needed to make a strong economy. It can't be done unless through Structural reforms with wide range that compatible with the market requirement for strengthen the role or the private sector and improving business climate and encouraged the foreign investment diversification of the economy (as discussed by International Monetary fund report in 2006, Report No. 06/137) [2].

The variety in financial instruments had led to diversification in a bunch of global financial indicators and the investors began to have difficulty in analyzing which direction they should follow due to continuous updating of several markets (as discussed by Tolga, 2011) [3].

This means that the timing is also important in the presentation of financial statements (as discussed by Erdogan Murat, 2002) [4]. Fiscal policy has an impact on financial assets (as discussed by Erdogan, 2006) [5].

Libyan's economy is suffering from a fluctuation in the flow of FDI during the last decade, so it can look into the causes of this volatility, and fiscal policy is one of the most important of these reasons.

Proceeding from the overall aim of the study, which focuses on the study of the impact of fiscal policy on foreign direct investment climate, in order to overcome the problems to provide a favorable investment climate, to attract the maximum amount of foreign investment into the Libyan economy, but the fact still prevents achieving the desired ambitions.

Where he was arranging to Libya to receive foreign direct investment, between 2000-2006 was 12 out of 22 Arab countries, it came in report Arab Investment Guarantee Corporation, for the year 2012-2013 that the order of Libya, 14 out of 22 Arab countries can be formulated research problem as follows: Is fiscal policy able to attract foreign direct investment? Hence, this study aims to identify the impact of fiscal policy on investment in Libya specifically, through their tools during the past decade for sixteen years, i.e. in the period during 2000-2015. 


\section{Literature Review}

There are a many books, studies and searches about the different sides for the fiscal policy subject and the foreign direct investments as a special subject in the advanced countries and the developing countries on the same side and this attempt to shows the most important studies which have the effect on the subject of this study.

\subsection{The Examining of GSM Operators' Customer Complaint Management (CCM) Applications in Turkey with Discriminant Analysis}

This study aims to evaluate the "solving the consumer's complaint for the Turkcell, Vodafone, Avea companies". And their performances related to CCM dimensions such as transparency, accessibility, responsiveness, objectivity and consumer oriented strategies is perceived by the consumers. Frequency distribution of survey data investigated and reliability of research variables tested by Cronbach Alpha analysis. Two discrimination functions were evaluated. With the first discrimination function, it is seen that the Avea has the highest value in comparison with the other companies (0.566); with the second discrimination function, it is seen that Vodafone has the highest value $(0.583)$. Turkcell has no highest discrimination value in comparison with the other GSM companies (as discussed by Yildiray \& Tahir, 2013) [6].

\subsection{The Impact of Fiscal Policy on Foreign Direct Investments: Empiric Evidence from Romania}

This article presents the impact of the fiscal and monetary policies on attracting the foreign direct investments (FDIs) in Romania, based on monthly data series during 20002010. Based on economic literature and on such empiric analysis, the article will propose some directions for the Romanian macroeconomic policy in the short-term in the context of crisis, because the FDIs are the engine for recovery and economic growth. In Romania, empiric results have shown that monetary factors such as higher interest rates and higher inflation attracted FDIs. Fiscal factors (mainly direct taxes) seem to play a less important role, being relevant only in the long-term. So, Romania should also focus on improving the other non-financial factors that greatly influence the investment environment here (infrastructure, legal and political stability) (as discussed by Magdalena \& Druicab, 2014) [7].

\subsection{Fiscal Policy Impacts on Particular Economic Sectors in Libya-Foreign Direct Investments}

This thesis aims to investigate whether foreign direct investment in Libya as the dependent variable is significantly related to the country's fiscal policy by considering variables of the fiscal policy. A simple linear regression model has been used to facilitate data analysis where the primary reason for applying this model is to succinctly investigate the type and extent of relationships existing between the dependent variable (FDI) and the independent variables in terms of the relationships' direction and strength 
through calculation of correlation coefficients. The SPSS Software has been used to conduct the data analysis were descriptive statistics, ANOVA analysis, correlations analysis, residual statistics, coefficients, regression statistics as well as a scatterplot and a histogram have been used for the examination of both the short-term and long-term relationship between independent variables and FDI in Libya. The result of this study shows that the fiscal policy changing one of the important specific factors for the foreign investments in Libya (as discussed by Abudeltef A.M. Galalh, 2013) [8].

\subsection{The Impact of Fiscal Policy on FDI in the Context of the Crisis}

This paper aims to analyze the impact of fiscal policy on FDI for Central and Eastern European countries (EU members) in the context of the recent global crisis. The study results at least one of the two most important instruments of fiscal policy-government revenue (tax revenue) and government expenditure - to have an important impact on FDI level, approved how the fiscal policy is important on attracting the investment as a solution for the recovery of the national economy (as discussed by Adina and Cristian, 2014) [9].

\subsection{Analysis of the Impact of Fiscal Policy on Investment in Nigeria}

This study is on "the impact of fiscal policy on investment expenditure in Nigeria. It covers the period of 1970 to 2010. A multiple regression model is specified in the study to assess the impact of fiscal policy on investment, using government expenditure, gross domestic product and corporate income tax. The estimation technique employed in this paper is the ordinary least squares (OLS) method. The study reveals that fiscal policy has a significant impact on investment expenditure in Nigeria. Government expenditure and gross domestic product have significant impact on investment, but corporate income tax has a positive, instead of a negative, impact on investment expenditure in Nigeria. Based on the findings, it is therefore recommended that the government should use an expansionary fiscal policy to encourage increase in investment in Nigeria and government spending should be channelled to capital projects and social overhead capital that will encourage investment, such as constant electricity supply and good road networks (as discussed by, Hassan \& Friday, 2015) [10].

\subsection{The Impact of Fiscal Policy on Gross Domestic Product in the European Union}

This study shows that private consumption has a positive influence on GDP, the rise in public debt has a negative influence on the evolution of GDP, government expenditure has an alternating influence that turns from positive in the first half of the observation period into negative in the second, the interest rate has a strong negative influence while the inflation rate has a positive influence on the evolution of GDP (as discussed by Talpos et al., 2013) [11]. 


\subsection{Effect of Fiscal Policy on Sectoral Output Growth in Nigeria}

The results of this study shows that the total fiscal spending has contributed in a positive way in let go all the sectors except the agriculture sector, as the study result epitomize that the industry sectoral has a positive relationship with all the united changes, and the study confirm that there is a disparity in sectoral response for the fiscal policy changes and how difficult it is to unified procedure and a wide fiscal policy, so that the best way is to depends a policy with specific sector based on the relative strength and how it's important for each sector with the general framework for the fiscal policy machinery (as discussed by Osinowo, 2015) [12].

\subsection{Tax as a Fiscal Policy and Manufacturing Company's Performance as an Engine for Economic Growth in Nigeria}

This study seeks to assess whether tax as a fiscal policy tool affect the performance of the selected manufacturing companies in Nigeria. To achieve the aims of the study, descriptive method was adopted and data were collected through the use of six years financial accounts of the selected companies. The hypothesis formulated for the study was tested with the ANOVA, using the Statistical Package for Social Sciences (SPSS). The study found that Taxation as a fiscal policy instrument has a significant effect on the performance of Nigerian manufacturing companies. The implication of the finding is that the amount of tax to be paid depends on the companies' performances. Based on the findings, it was recommended among others that the government is required to be sensitive to the variables in the tax environment and other macro-environmental factors so as to enable the manufacturing sector cope with the ever changing dynamics of the manufacturing environment (as discussed by Ezejiofor \& Echekoba, 2015) [13].

\subsection{The Impact of Fiscal Policy on Nigeria's Economic Growth} (1970-2013)

The research is aimed at evaluating the relationship between fiscal policy and economic growth in Nigeria. The research employed the co-integration error correction mechanism (ECM). The result revealed that there exist a long-run equilibrium relationship between economic growth and fiscal policy variables in Nigeria. However, the outcome of our analysis shows that the effects of fiscal variables on economic growth are positive but statistically insignificant. An increase in government expenditure and fiscal deficit as well as tax revenue will lead to an enhancement in economic stability. The study recommended that government should endeavor to formulate and implement viable fiscal policy mix as well as diversifying the nation's economic base (as discussed by Kingsley \& Darius, 2015) [14].

\section{Theoretical Review}

The history of the foreign direct investment in the developing countries is go back to the nineteenth century, when this investment focused through the periods of colonial- 
ism in metals, agriculture and general services, and the beginning of the twentieth century had witness a revolution of a big parts of the infrastructure in different places in world through the foreign direct investment, in electricity field (for example, as discussed by Tahir \& Kizgin, 2013) [15], and the wire communications and the wireless Ghazali when it was in the historical stages for the foreign direct investment and the different degree of the political and economic conditions which affect to the size, nature and structure of the foreign investment (as discussed by Portia, 2011) [16].

According to international and economists experts, these revolutions have been divided into four main stages.

\subsection{The First Stage}

This stage presents the traditional image for the foreign investment which called Colonial-style and its being like the source of capital from the foreign country present it to an underdeveloped country which is in the projects related with exploit its resources and the basic raw materials, when the foreign source from that country, the basic raw materials has been exported to all country world at cost price, and the host country buy it later in a doubles price, and this concept have been knowing in the era of the colonial domination on the foreign capital and this stage has been continued until the end of the Second World War.

The stage before the First World War, which generally means the stage between 1870-1914 the economic and the political states are characterized with flowing of the foreign direct investment, and its back to many reasons, of which: Availability of investment opportunities in the colonies, exchange rate stability in circumstance of the gold stander, and the protection of the colonial powers for the foreign investment, generally the effective control through this time was belong to London market as a source for capital to another countries, the industrial revolution in Europe created a strong demand for the food materials and the raw materials which notes a large expansion in size of international finance.

With the beginning of 1914 the accumulated balance from the foreign direct investments reached fifteen Billion dollar, and Britain was the biggest source when the united state and Germany came next to it. In 1983 the cost of the foreign direct investment reached to sixty six billion dollar, and this stage has characterized with drooping in the foreign direct investment and its came on largely to the conditions of the world war, the disturbed, the political and economic instability, the breakdown of the gold stander, the increase which came with the size of private borrowing and the recession and deflation, where the foreign direct investment was basically based on the investment in the oil sector and railroad building.

\subsection{The Second Stage}

The change of the manner of the foreign direct investment, after the Second World War, the Bretton Woods conference in 1944 has selected the international economic 
system after the war led to build up the international monetary fund and the international bank for reconstruction and development and the dollar become the principal reserve currency, had mentions in economic revival program in 1974 (Marshall Plan), which aims to rebuilding Europe after the war, and this stage characterized with using the fiscal and technique assistance and the official grants whish linked to the foreign funding in the general sector, in this stage the foreign direct investment was uncommon where the foreign funding for the developing country which depended on the official development assistance, while in the middle of fifty the foreign direct investment has notes a recognizable improvement and this stage has extended until 1973 (as discussed by Wikipedia, the free encyclopedia (October 2010) in 25/5/2016) [17].

\subsection{The Third Stage}

Which spread during the time 1973-1982, and this stage had notes a significant increase with the foreign funding which directed to the developing countries, and it has evolved in terms of patterns of financing in form of commercial loans, foreign assistance and grants to the developing countries to leave the rules and banking standards, the commercial banks have controlled over $65 \%$ of all sources of foreign funding for the developing countries, the debt of the developing countries increased ten times to become 686,000,000,000 American dollar in 1984.

\subsection{The Fourth Stage}

Through this time the ability of the developing countries has deteriorated because of the service dept, and after that in 1974 where the average of dept has risen to the cross national income to more than double, where it rising from $14 \%$ in 1970 about to $34 \%$ in 1984, in general this stage has started in 1982 while some countries have notes their inability to repayment the debt which owed to them, then this leaded to reducing the loans, grants and the size of official aid, and this loans become submitted to the certificate from the International Monetary Fund to ensure the right of repayment, the problem of the finance is a fundamental problems which force the development countries to achievement the economic development, and the absence of the actual savings to achieving the economic development, through this global debt crisis the complexity of the procedures for obtaining a loans and grant and it was imperative for the developing countries to improve the climate to attract the foreign investment locally and internationally, in the beginning of ninety the foreign direct investment knew a powerful development through increase the investments implemented, it moved from fifty billion dollar in 1990 to 3500 billion dollar in 1996 which reached to 9000 billion dollar in 2004, the development went back to the size of the investment in many of countries with multiple nationalities where it reached about 70,000 companies numbered, plus to the technological improvement, the globalization, the search and the development.

The stock market is one of the most important sources for companies to raise money. 
History has shown that the price of a share is an important part of economy. It is generally known that investors and investments are also physical particles of stock markets especially in country economies (as discussed by Ulusoy, Keskin, M., Keskin, M., Deviren, Kantar \& Dönmez, 2012) [18].

\section{Benchmark Analysis for the Influential Factors on the Foreign Investment}

For aim of diagnosis for the fiscal policy tools which effect in attracting the foreign direct investment to Libyan economy, the linear regression form will applied by the time series During the period (2000-2015) according to a Libyan official data which published about the changes that mentioned through the study period.

\subsection{The Study Variants}

\subsubsection{The Gross Domestic Product}

This signal usually used to indication on the economic development levels from side and the production capacity from the other side and what it entails that the possibilities for achieving the capital accumulation, and what this accumulation leading to Achieving continuous progress with the production and productivity level, as the economic growth index include as one of the important indexes which used by the investors in their investment choices, when the weak performance for the economic growth usually prevents to expansion the foreign direct investment based, and it including as the most important indexes which used by the investors to known the degree of the economic stability and the level of overall demand and entering so that it's been expected that it will has a positive relationship with the flows of the foreign direct investment.

The Gross Domestic Product value of Libya represents 0.05 percent of the world economy. GDP in Libya averaged 42.34 USD Billion from 1990 until 2015, reaching an all time high of 87.14 USD Billion in 2008 and a record low of 20.48 USD Billion in 2002. Figure 1 shows a series of net outflows of GDP in Libyan economy (2000-2015) (trading, economics) [19].

\subsubsection{The Government Spending}

The public expenditure considered as an important instrument of fiscal policy for the country, it shows in a big way the activity of the government and how much it effective on the economic activity, the public expenditure according as a part of the total request there for its effect on the affective request which is contributes in raise the employment levels, make a job opportunities, combat unemployment, increase the rate of the economic growth and the social welfare.

World Bank definition: General government final consumption expenditure includes all government current expenditures for purchases of goods and services. It also includes most expenditures on national defense and security, but excludes government military expenditures that are part of government capital formation. Data are in current U.S. 


\section{Gross domestic product}

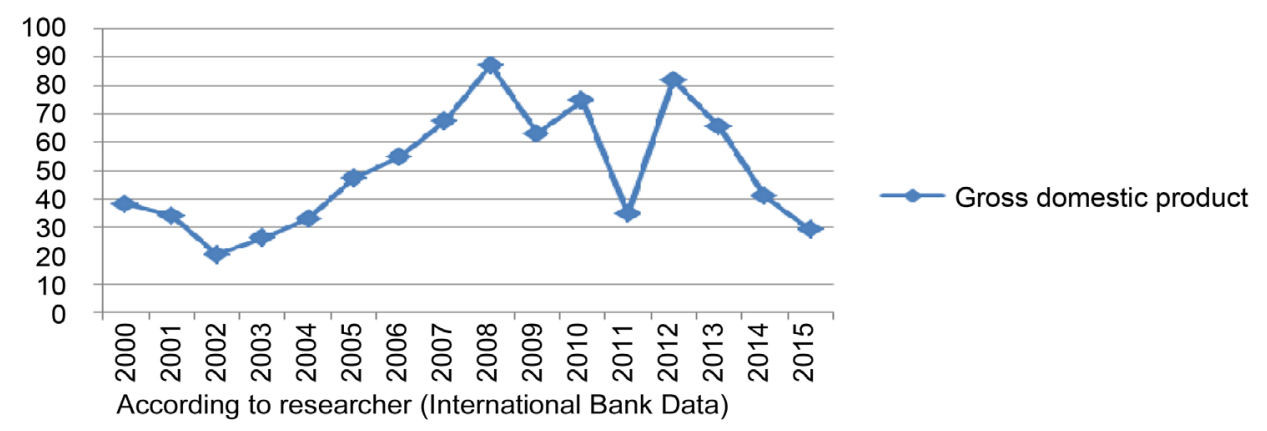

Figure 1. The evolution of GDP in the Libyan economy (2000-2015).

dollars, the government expenditure value in Libya from 2000 until 2014, reaching an all time high of 61.83 USD Billion in 2013 and a record low of 18.29 USD Billion in 2002. Figure 2 shows a series of the government expenditure value in Libyan economy (2000-2014).

\subsubsection{The Investment Expenditures}

Foreign direct investment into Libya was 0.05 billion USD in 2014 which is 0.12 percent of GDP. We look primarily at the percent of GDP as opposed to the dollar amounts because larger economies would normally attract greater volumes of foreign investment. Values above 4 - 5 percent of GDP suggest that the country is an attractive foreign investment destination. The Foreign direct investment in Libya is reported by the World Bank. Figure 3 shows a series of The Investment expenditures in Libyan economy (2000-2014).

\subsection{Apply a Linear Regression}

It will be applying a diverse linear regression modal by time series including Libyan official data which published in period 2000-2015.

As notes from Table 1 that the value of the correlation coefficient between the gross domestic product and the invest expenses is 0.726 which means there is correlation an extrusive strong which has morale because of the moral value is 0.003 which is less than 0.05 .

As notes from Table 2 the value of the correlation coefficient between the government spending and the invest expenditures is 0.274 which is an extrusive weak relationship and not morale because the moral value is 0.343 which means there is no connection between the government spending and the investment expenditures, now let's make the regression equation for each of the former variables.

We notes that the value of the regression equation between the variables is 0.81 which means $65 \%$ of the factor effect will be explaining by this equation as notes from Table 3.

The regression equation is looks as follows from Table 4.

The investment expenditures $=715,927,144+0.075$ (the gross domestic product) 0.48 (the government spending). 


\section{Government spending}

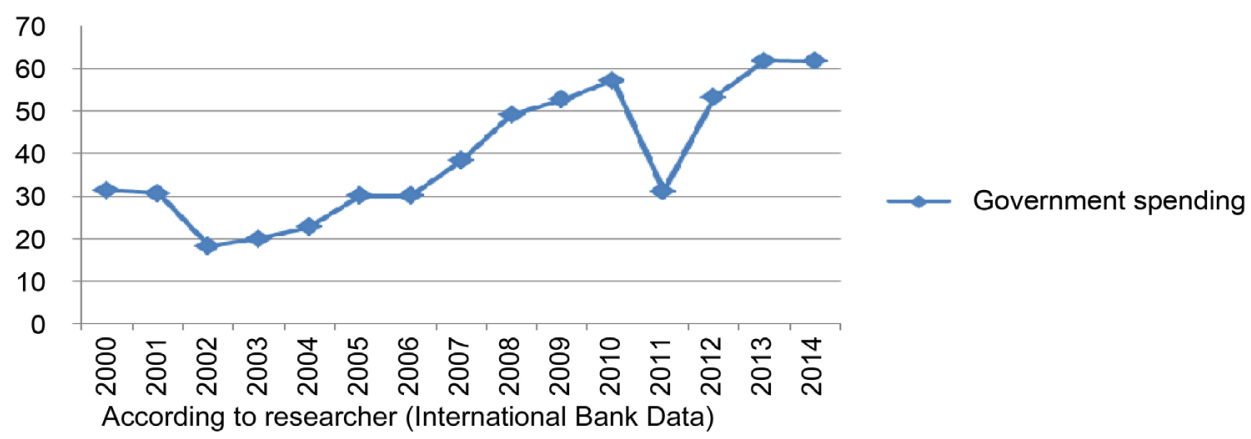

Figure 2. The evolution of government expenditure in Libya (2000-2014).

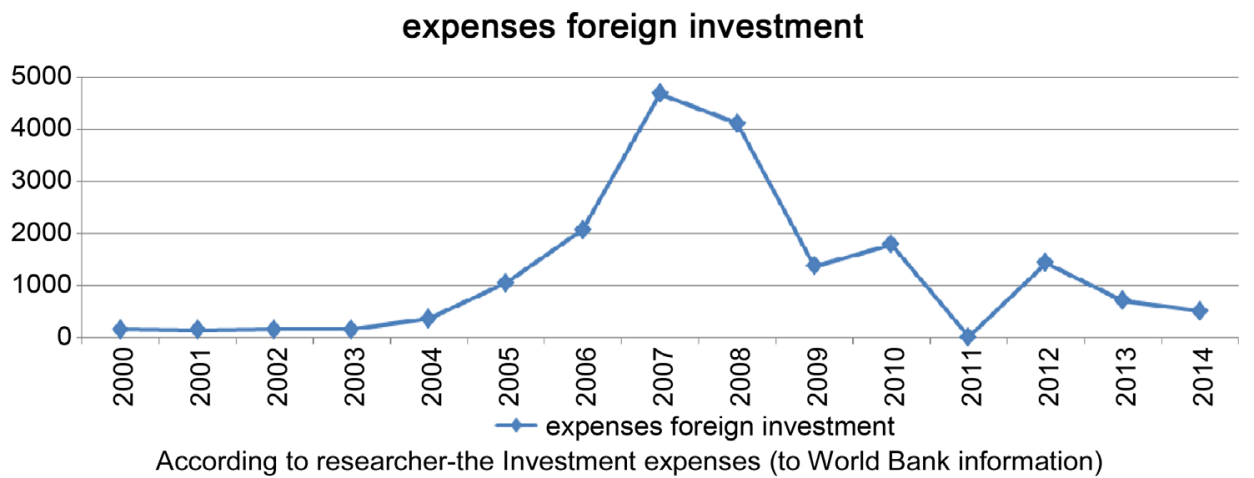

Figure 3. The investment expenses in Libya (2000-2014).

Table 1. The correlation coefficient between the gross domestic product and the invest expenses.

\begin{tabular}{cccc}
\hline & & Investment Expenses & Gross Domestic Product \\
\hline & Pearson Correlation & 1 & $0.726^{* *}$ \\
Investment Expenses & Sig. (2-tailed) & & 0.003 \\
& $\mathrm{~N}$ & 14 & 14 \\
\hline
\end{tabular}

Table 2. The correlation coefficient between the government spending and the investment expenses.

\begin{tabular}{cccc}
\hline & & Investment Expenses & Government Spending \\
\hline & Pearson Correlation & 1 & 0.274 \\
Investment Expenses & Sig. (2-tailed) & & 0.343 \\
& $\mathrm{~N}$ & 14 & 14 \\
\hline
\end{tabular}

Table 3. Model summary.

\begin{tabular}{ccccc}
\hline Model & $\mathrm{R}$ & R Square & Adjusted R Square & Std. Error of the Estimate \\
\hline 1 & 0.81 & 0.65 & 0.59 & $928,678,003.9$ \\
\hline
\end{tabular}

And after we deleted the government spending variable, looks as follows from Table 5.

The regression equation is looks as follows through Table 5. 
Table 4. Coefficients.

\begin{tabular}{|c|c|c|c|c|c|}
\hline \multirow{2}{*}{ Mode } & \multicolumn{2}{|c|}{$\begin{array}{l}\text { Unstandardized } \\
\text { Coefficients }\end{array}$} & \multirow{2}{*}{$\begin{array}{c}\text { Standardized } \\
\text { Beta }\end{array}$} & \multirow{2}{*}{$\mathrm{t}$} & \multirow{2}{*}{ Sig } \\
\hline & B & Std. Error & & & \\
\hline 1 (Constant) & 715.927 .144 & 739646854.8 & & 0968 & 0354 \\
\hline Gross domestic & $\begin{array}{l}70,921,144 \\
0.075\end{array}$ & $\begin{array}{c}139,040,834.8 \\
0.017\end{array}$ & 1.099 & 4.307 & 0.001 \\
\hline $\begin{array}{c}\text { product } \\
\text { Government spending }\end{array}$ & 0.048 & 0.024 & 0.518 & 2.029 & 0.067 \\
\hline
\end{tabular}

Table 5. Coefficients.

\begin{tabular}{cccccc}
\hline \multirow{2}{*}{ Model } & \multicolumn{2}{c}{ Unstandardized Coefficients } & Standardized & \multirow{2}{*}{$\mathrm{t}$} & Sig \\
\cline { 2 - 3 } & $\mathrm{B}$ & Std. Error & Beta & & \\
\hline $\begin{array}{c}\text { 1 (Constant) } \\
\text { Gross }\end{array}$ & $-1,286,330,392.112$ & $767,842,667.813$ & & -1.675 & 0.120 \\
domestic product & 0.050 & 0.014 & 0.726 & 3.655 & 0.003 \\
\hline
\end{tabular}

Invest expenses $=-1286330392+0.050$ (the gross domestic product.

And now let's study the stability of the time series according to the test of unit root.

\subsubsection{Stability of Investment Expenditures}

For the stability of the time series is necessary that the calculated value is greater than the tabular value.

And now let's study the stability of the time series according to the test of Dickey-Fuller Developer:

As notes from Table 6 that the calculated value of $t$ is less than the tabular value so that we will accept the null hypothesis which said that the series have unit root there for the series is unstable, now let's studying the stable of series after we did calculate the first difference:

As notes from Table 7 that the calculated value of $t$ is bigger than the tabular value in the degree of confidence $5 \%$ there for the earlier series is stable and have no unit root and that's after calculated the first difference.

\subsubsection{Stability of the Gross Domestic Product}

As notes from Table 8 that the calculated value of $t$ is less than the tabular value so that we will accept the null hypothesis which said that the series have unit root there for the series is unstable.

Now let's studying the stable of series after we did calculate the first difference:

As notes from Table 9 that the calculated value of $t$ is bigger than the tabular in the degree of confidence $5 \%$, therefor the earlier series is stable and have no unit root and that's after calculated the first difference.

And to find the regression equation after we calculate the first different, the equation will look like: 


\begin{tabular}{ccccc}
\hline Variable & Coefficient & Std. Error & t-Statistic & Prod \\
\hline C & 0.76 & 3.00 & 0.256272 & 0.8029 \\
DGDP & 0.048 & 0.020 & 2.391700 & 0.0378 \\
\hline
\end{tabular}

$\mathrm{INV}=0.76+0.048 * \mathrm{GDP}$.

\section{The Implications of the Results}

The study shows that the gross domestic product has a positive effect on the investment

Table 6. Unit root test at the level of INV.

NuII Hypothesis: INV has a unit root

Exogenous: Constant

Lag Length: 0 (Automayic-based on SIC, maxlag = 2)

\begin{tabular}{ccc}
\hline & t-Statistic & Prod $^{*}$ \\
\hline Augmented Dickey-Fuller test statistic & -1.436823 & 0.05292 \\
& & \\
Test critical values: & $1 \%$ level & -4.121990 \\
& $5 \%$ level & -3.144920 \\
& $10 \%$ level & -2.713751
\end{tabular}

Table 7. Unit root test at the first difference of INV.

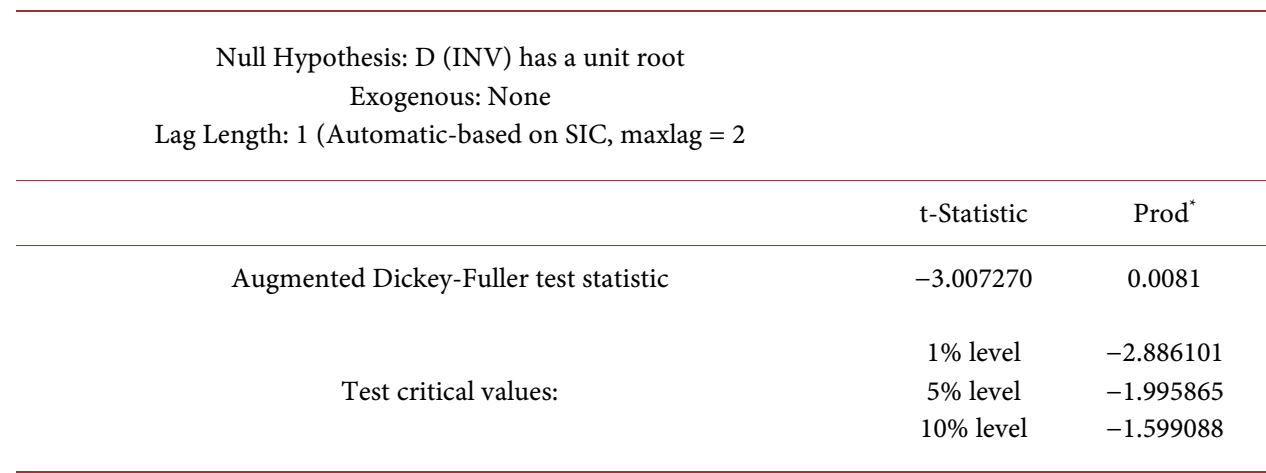

Table 8. Unit root tests at the level of GDP.

Null Hypothesis: GDP has a unit root

Exogenous: Constant

Lag Length: 0 (Automatic-based on SIC, maxlag = 3)

\begin{tabular}{ccc}
\hline & t-Statistic & Prod $^{*}$ \\
\hline Augmented Dickey-Fuller test statistic & -2.133008 & 0.2359 \\
& & \\
Test critical values: & $1 \%$ level & -4.004425 \\
& $5 \%$ level & -3.098896 \\
& $10 \%$ level & -2.690439
\end{tabular}


Table 9. Unit root tests at the first difference of GDP.

\begin{tabular}{ccc}
\hline $\begin{array}{c}\text { Null Hypothesis: D (GDP) has a unit root } \\
\text { Exogenous: None }\end{array}$ & \\
Lag Length: 0 (Automatic-based on SIC, maxlag = 3) & \\
\hline & t-Statistic & Prod $^{*}$ \\
\hline Augmented Dickey-Fuller test statistic & -5.611523 & 0.0000 \\
& & \\
Test critical values: & $1 \%$ level & -2.754993 \\
& $5 \%$ level & -1.970978 \\
& $10 \%$ level & -1.603693 \\
\hline
\end{tabular}

spending in Libya, and the increasing of the gross domestic product or the incoming will lead to increasing in the investment spending in Libya during the study period (20002015). And the unit increasing in the gross domestic product will lead to... $0.048 \ldots$ unit increase in the investment spending.

And the study shows that the government spending has no positive effect on the investment spending in Libya during the study period (2000-2015). It shouldn't suppose to give the using of this tool a prominent interesting.

\section{Results and Recommendations}

1) For increasing the level of the investment spending in Libya, the policy maker should make more of focus on using the gross domestic product as a tool of the fiscal policy tools and increasing the investment.

2) The government spending has no big effect on the investment spending in Libya during the period 2000-2015.

And the study shows that the gross domestic product has a big effect on the investment spending in Libya, but the government spending has no big effect on the investment spending.

\section{References}

[1] International Monetary Fund (2012) Libya beyond the Revolution: Challenges and Opportunities. 1.

[2] International Monetary Fund (2006) IMF Country Report No. 06/137, Medium-Term Economic Reform Strategy, and Statistical Appendix, Libya. 3.

[3] Ulusoy, T. (2011) Financial Power Analysis of Countries: Transmitters (Adsorbents), Setters and Unresistants. African Journal of Business Management, 5, 9087-9105.

[4] Erdogan, M. (2002) As a Means of Executive Decision-Making in Line with Turkey Accounting Standards and Uniform Accounting System Financial Accounting.

[5] Erdogan, M. (2006) Farkli Faydali Ömürlere Sahip Olan Maddi Varliklarin Bilesenlerinin Amortismani. Muhasebe ve Finansman Dergisi, No. 29.

[6] Kizgin, Y. and Benli, T. (2013) The Examining of GSM Operators' Customer Complaint Management. 
[7] Rădulescu, M. and Druica, E. (2014) The Impact of Fiscal Policy on Foreign Direct Investments. Empiric Evidence from Romania. Economic Research-Ekonomska Istraživanja, 27, 86-106.

[8] Galalh, A.A.M. (2013) Fiscal Policy Impacts on Particular Economic Sectors in Libya-Case of Study Foreign Direct Investments. https://www.pef.czu.cz/dl/46000

[9] Dornean, A. and Oanea, D.C. (2014) The Impact of Fiscal Policy on FDI in the Context of the Crisis. Evidence from Central and Eastern European Countries. Procedia Economics and Finance, 15, 406-413. https://doi.org/10.1016/S2212-5671(14)00468-7

[10] Akpo, E.S., Hassan, S. and Friday, C. (2015) Analysis of the Impact of Fiscal Policy on Investment in Nigeria. http://ijecm.co.uk/wp-content/uploads/2015/05/3528.pdf

[11] Talpos, I., Avram, A. and Hetes, R. (2013) The Impact of Fiscal Policy on Gross Domestic Product in the European Union. A Panel Var Model Aproach. Annales Universitatis Apulensis: Series Oeconomica, 15, 605.

[12] Osinowo, O.H. (2015) Effect of Fiscal Policy on Sectora Output Growth in Nigeria. Advances in Economics and Business, 3, 195-203.

[13] Ezejiofor, R.A., Adigwe, P.K. and Echekoba, F.N. (2015) Tax as Fiscal Policy and Manufacturing Company's Performance as an Engine for Economic Growth in Nigeria. European Journal of Business, Economics and Accountancy, 3, No. 3.

[14] Kingsley, A.W. and Darius, I. (2015) The Impact of Fiscal Policy on Nigeria's Economic Growth (1970-2013). International Journal of Marketing and Technology, 5, 10-22.

[15] Benl, T., Kizgin, Y., Karaosmanoglu, K. and Hiz, G. (2013) A Field Study on the Determination of the Card Users' Awareness of the Products/Services Offered with Cards: Turkey Case. International journal of Business and Management, 8, 13.

[16] Bukari, P.A. (2011) Foreign Direct Investment: How Beneficial Is It?

[17] http://ijecm.co.uk/wp-content/uploads/2015/05/3528.pdf

[18] Ulusoy, T., Keskin, M., Shirvani, A., Deviren, B., Kantar, E. and Dönmez, C.Ç. (2012) Complexity of Major UK Companies between 2006 and 2010: Hierarchical Structure Method Approach. Physica A, 391, 5121-5131. https://doi.org/10.1016/j.physa.2012.01.026

[19] http://www.TRADINGECONOMICS.COM

\section{Submit or recommend next manuscript to OALib Journal and we will provide best} service for you:

- Publication frequency: Monthly

- 9 subject areas of science, technology and medicine

- Fair and rigorous peer-review system

- Fast publication process

- Article promotion in various social networking sites (LinkedIn, Facebook, Twitter, etc.)

- Maximum dissemination of your research work

Submit Your Paper Online: Click Here to Submit

Or Contact service@oalib.com 